\title{
Spatial genetic structure in the Eurasian otter (Lutra lutra) meta-population from its core range in Italy
}

\section{Maria Buglione}

Department of Biology, University of Naples Federico II, Via Cinthia 26, 80126 Naples, Italy

\section{Simona Petrelli}

Department of Biology, University of Naples Federico II, Via Cinthia 26, 80126 Naples, Italy

\section{Claudia Troiano}

Department of Humanities, University of Naples Federico II, Via Porta di Massa 1,

80133 Napoli, Italy

\section{Tommaso Notomista}

Department of Biology, University of Naples Federico II, Via Cinthia 26, 80126 Naples, Italy

\section{Antonio Petrella}

Istituto Zooprofilattico Sperimentale della Puglia e della Basilicata, Via Manfredonia, 71121 Foggia, Italy

\section{Laura De Riso}

Ente Parco Nazionale del Cilento, Vallo di Diano e Alburni, Via F. Palumbo 18, 84078 Vallo della Lucania, Italy

\section{Luigi Poerio}

A.S.D. Pollino Discovery, Via Carella 35, 85040 Viggianello, Italy

Vito Cascini

A.S.D. Pollino Discovery, Via Carella 35, 85040 Viggianello, Italy

\section{Remo Bartolomei}

Studio Naturalistico Wildlife Research, Via Provinciale 163, 8505o Marsicovetere, Italy

\section{Domenico Fulgione}

Department of Biology, University of Naples Federico II, Via Cinthia 26, 80126 Naples, Italy fulgione@unina.it 


\section{Abstract}

We characterized the genetic structure of the Eurasian otter (Lutra lutra) meta-population living in the core of its Italian distribution range providing results from 191 fresh spraints, collected from 24 watercourses included in Southern Italy. Furthermore, according to ecological corridors and barriers, we discuss the likely ways of movement and possible evolutionary fate of these populations. We genotyped 136 samples using 11 Lut microsatellite nuclear markers amplified from faecal DNA. Microsatellites were moderately variable $\left(\mathrm{H}_{\mathrm{o}}=0.45 ; \mathrm{H}_{\mathrm{e}}=0.46\right)$, with a total number of alleles and average number of alleles per locus in the meta-population of 5 o and 4.54, respectively. No significant heterozygosity excess was observed in meta-population suggesting no recent population bottlenecks. Bayesian clustering discriminated a sub-structuring of the meta-population in five putative clusters, indicating that local populations are genetically differentiated: three of these seem to be identifiable with geographically defined sub-populations (from the Cilento, Agri and Basento river basins). The fourth is represented by multiple sub-populations with admixed genotype, that include genotypes from the Lao, Sinni and Abatemaco river basins, living in a landscape with the higher environmental permeability. Landscape genetic analysis could provide evidence of an unexpected ecological corridor: the seacoast, highlighted, for the first time as a new way for the dispersion of the South-Italian otters. Deepening the knowledge of these perspectives is crucial to identify solid strategies aimed at the future health of the populations of the Italian otters, by restoring dispersal corridors and managing the watercourses.

\section{Keywords}

conservation - ecological corridor - microsatellite - non-invasive genetics - river - spraint

\section{Introduction}

The Eurasian otter (Lutra lutra, Linnaeus 1758) has suffered a marked decline in many European countries during the second half of the twentieth century, due to the combination of global and local factors, such as human persecution, pollution, and habitat fragmentation (Mason, 1995; Murk et al., 1998; Conroy \& Chanin, 2000; Mason \& Wren, 2001; Ruiz-Olmo et al., 2002; Panzacchi et al., 2011; Scorpio et al., 2016).

In Italy, this severe decrease determined the total disappearance of the otter in the northern part of the peninsula (Macdonald \& Mason, 1983; Cassola, 1986; Macdonald \& Mason 1994; Prigioni et al., 2007) and its gradual decline in the central and in the southern areas (Boitani et al., 2003; Prigioni et al., 2007), causing a range reduction down to a few regions, mainly Basilicata and Campania (Prigioni, 1997; Panzacchi et al., 2011; Balestrieri et al., 2016).

Nowadays, the Eurasian otter is classified as Near Threatened at global level (Duplaix \& Savage, 2018). In Italy, although it is listed as Endangered (D category) in the IUCN (International Union for Conservation of Nature) Red List (Panzacchi et al., 2011), the populations of Central-Southern Italy are currently expanding northward (Prigioni et al., 2007; Balestrieri et al., 2008; Loy et al., 2010; Giovacchini et al., 2018).

Since 1990, it was reported that the structure of the Italian otter population was organized in two sub-populations isolated 
from each other: a small and isolated nucleus living in the Abruzzo and Molise regions (central Italy), and a larger core population along the river networks of the Campania, Basilicata, Apulia and Calabria regions (Southern Italy) (Fusillo et al., 2004; Loy et al., 2004; Marcelli, 2006; Lerone et al., 2014; Balestrieri et al., 2016; Giovacchini et al., 2018). Furthermore, recently, otter presence has been recorded in the North-Eastern of the peninsula, as a consequence of the expansion of Austrian and Slovenian populations (Kranz, 2008, pers. comm.; Lapini \& Bonesi, 2011, pers. comm.; Righetti, 2011, pers. comm.; Pavanello et al., 2015).

The latest survey, conducted in the Molise, Basilicata, Campania, Calabria and Apulia regions, estimated the current otter population size to be lower than 1000 individuals, more likely 229-257 individuals (Prigioni et al., 2006a, b). This Italian cluster is geographically and genetically isolated from all otter populations living in Europe (Spagnesi, 2002; Randi et al., 2003). This isolation, combined with local adaptations, might lead to genetic differentiation in a unique evolution trajectory. The evolutionary fate could depend mainly on mutual isolation and/or connection among sub-populations, which could affect the level of gene flow within and between demes, and consequently their genetic profile. This could lead to the consideration of the Italian otter as an Evolutionary Significant Unit (ESU) and thus a species of special conservation interest due to its uniqueness (Randi et al., 2003; Mucci et al., 2010; Bertolino et al., 2015), as it happens for some other mammal species in Southern Italy, like Lepus corsicanus (Alves et al., 2008; MeloFerreira et al., 2012; Buglione et al., 2020a), Sorex minutus (Vega et al., 2010), and Myodes glareolus (Colangelo et al., 2012).

Here, we genotype samples using DNA from scat (spraints) to characterize, for the first time, the structure of the Italian otter meta-population living in the core part of its distribution range (Southern Italy), including Basilicata, Campania, Calabria and Apulia regions, that account for more than $70 \%$ of the species' range in Italy (Prigioni et al., 2005). The river basins that we considered host stable otter populations (Prigioni et al., $2006 \mathrm{~b}$ ), and represent precious ways of connection between the otter populations of different regions in Southern Italy (Smiroldo et al., 2009). Furthermore, considering ecological corridors and barriers, in light of the genetic structure of the populations, we hypothesized the environmental variables affecting dynamics of expansion, in order to predict the likely ways of movement and possible evolutionary fate of these populations. Deepening the knowledge of these perspectives is crucial to identify solid strategies aimed at the conservation of the Italian otters, ensuring the preservation of its evolutionary potential. Conservation actions could be directed to those watercourses that play an important role in the dispersal of the Italian otter populations. Furthermore, according to IUCN guidelines (IUCN, 1998), the definition of the genetic structure of populations is mandatory for reintroduction actions, to avoid unexpected consequences and genetic pollution (Van Ewijk et al., 1997; Saavedra \& Sargatal, 1998; Arrendal et al., 2004). This could be useful for otters when they can no longer naturally colonise a territory because of isolation of the populations or eradication (Mucci et al., 2010).

\section{Materials and methods}

\section{Study area and sampling}

From May to December 2018, we conducted an extensive field survey, monitoring a total of 24 watercourses included in the Campania, Basilicata, Calabria and Apulia 
regions (southern Italy, $40^{\circ} 40^{\prime} \mathrm{N}, 39^{\circ} 37^{\prime} \mathrm{N}$ ) (fig. 1 and table 1). We collected 191 spraints, according to the standard method proposed by Reuther et al. (2000), selecting only fresh scats (spraints $<2$ day old) (Santini et al., 2007; Buglione et al., 2018; Buglione et al., $2020 \mathrm{~b}$ ), aged by field collectors using odor and aspect. To ensure the best collection, old spraints, were removed the day before each sampling session and collection was performed in the following early morning to limit DNA degradation (Taberlet et al., 1996; Dallas et al., 2000; Goossens et al., 2000; Jansman et al., 2001). The external layer of the spraints, which contains sloughed gut cells, was wiped off with a sterile cotton swab, placed in a sterile tube with $500 \mathrm{~mL}$ of Buffer (QIAGEN, Valencia, CA) (Lampa et al., 2008 ) or with $70 \%$ ethanol (only in rare cases where the buffer was no longer sufficient), and stored at $-20^{\circ} \mathrm{C}$.

The geographical location of samples was mapped using QGIS v.3.4.1 software (QGIS Development Team, 2019) and the locations were then grouped according to the river basin where they were collected (table 1). The definition of river basins was performed by plotting the entire river network in GIS environment and drawing a buffer area of 1 $\mathrm{km}$ around all waterways connected to the main river. The samples that did fall within any river basin were marked as "out of basin" (table 1).

\section{Population genetics of neutral loci}

To prevent contamination, spraints were analysed in a laboratory designed for non-invasive genetics, free from mammal DNA, including

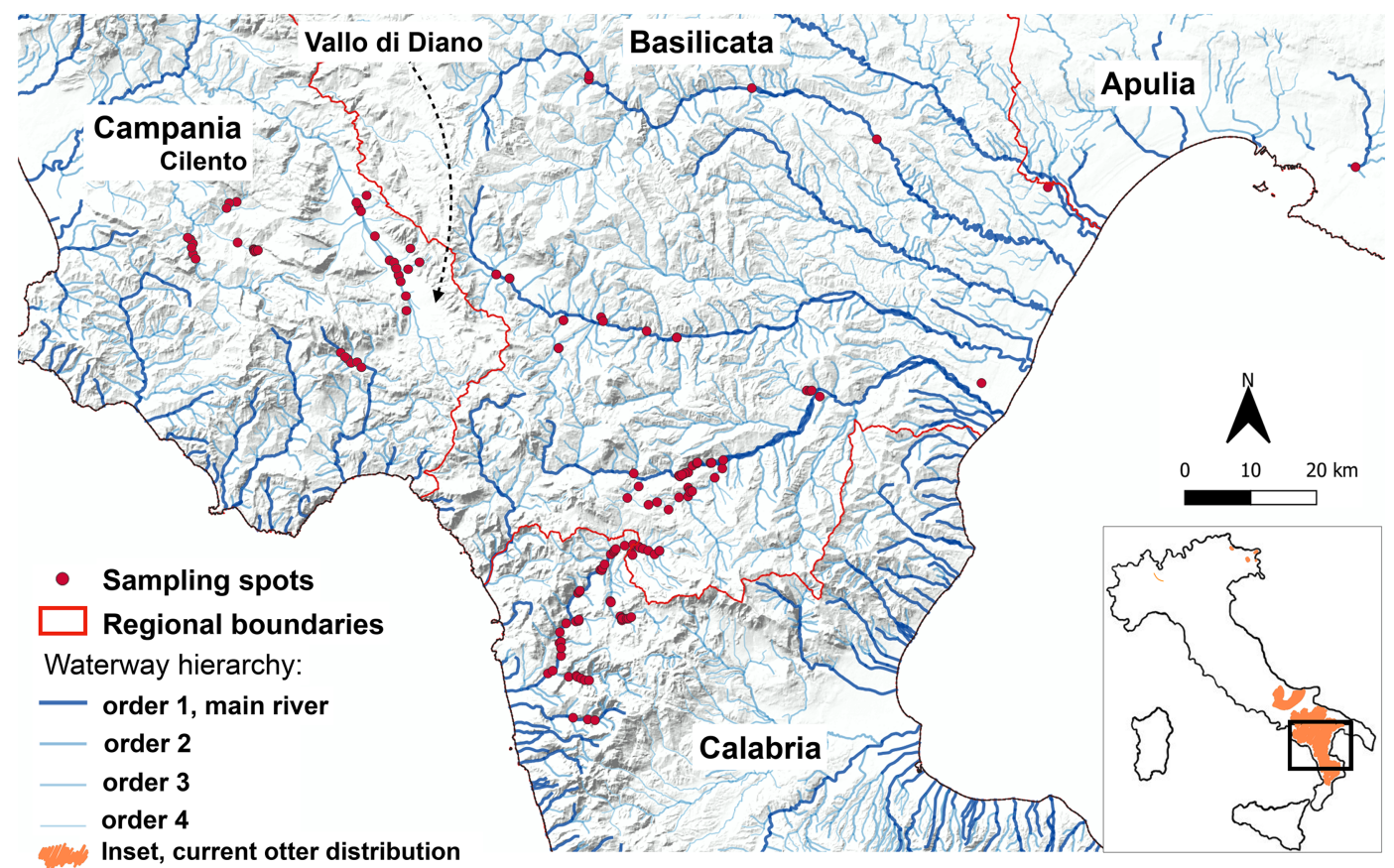

FIGURE 1 The area surveyed for collection of otter samples $\left(40^{\circ} 40^{\prime} \mathrm{N}, 39^{\circ} 37^{\prime} \mathrm{N}\right)$. Red spots indicate the location of the collected samples. The blue lines highlight the main rivers (order 1 ) and their tributaries (order 2, 3 and 4 according to waterway hierarchy). The continuous red lines represent regional boundaries. In the inset, the current otter distribution (inferred from Balestrieri et al., 2016, modified) is reported in orange and the study area is defined by the black bold square. 
TABLE 1 Watercourses surveyed for the collection of the otter samples, their corresponding region of origin, type (MR, main river; L, lake; S, stream; T, tributary), number of collected samples and river basin to which they were assigned; out of basin, samples that were not assigned to any river basin

\begin{tabular}{|c|c|c|c|c|c|}
\hline & Watercourse & Region & Type & Number of samples & River basin \\
\hline & Abatemarco & Calabria & MR & 3 & Abatemarco \\
\hline & Agri & Basilicata & MR & 9 & Agri \\
\hline & Argentino & Calabria & MR & 7 & Lao \\
\hline & Basento & Basilicata & MR & 4 & Basento \\
\hline & Battendiero & Calabria & $\mathrm{T}$ & 13 & Lao \\
\hline & Bradano & Basilicata & MR & 1 & out of basin \\
\hline & Bussento & Campania & MR & 12 & Cilento \\
\hline & Calore & Campania & $\mathrm{T}$ & 6 & Cilento \\
\hline & Caolo & Basilicata & MR & 5 & Agri \\
\hline & Fasanella & Campania & $\mathrm{T}$ & 22 & Cilento \\
\hline & Frido & Basilicata & $\mathrm{T}$ & 7 & Sinni \\
\hline & Galeso & Apulia & $\mathrm{S}$ & 1 & out of basin \\
\hline & Grondo & Calabria & $\mathrm{T}$ & 1 & Lao \\
\hline & Pietra del Pertusillo Lake & Basilicata & $\mathrm{L}$ & 3 & Agri \\
\hline & Lao & Calabria & MR & 20 & Lao \\
\hline & Maglia & Basilicata & $\mathrm{T}$ & 2 & Agri \\
\hline & Mercure & Basilicata & MR & 11 & Lao \\
\hline & Paraturo & Basilicata & $\mathrm{T}$ & 2 & Lao \\
\hline & Peschiera & Basilicata & $\mathrm{T}$ & 6 & Agri \\
\hline & Sarmento & Basilicata & $\mathrm{T}$ & 1 & Sinni \\
\hline & Melandro & Basilicata & $\mathrm{T}$ & 4 & Agri \\
\hline & Sciaura & Basilicata & $\mathrm{T}$ & 3 & Agri \\
\hline & Sinni & Basilicata & MR & 22 & Sinni \\
\hline & Tanagro & Campania & $\mathrm{T}$ & 26 & Cilento \\
\hline Total & 24 & 4 & & 191 & 6 \\
\hline
\end{tabular}

both distinct pre- and post-PCR rooms, with separate and sterilized equipment (i.e. aerosol-resistant pipette tips, disposable sterile gowns) for DNA extraction, PCR (with a laminar flow hood), and post-PCR processing. Genomic DNA was extracted using QIAamp DNA Stool Mini Kit (QIAGEN, Valencia, CA), according to manufacturer's instruction. Three negative controls were included in each extraction to monitor the performance of the process and to exclude potential cross-contaminations. The concentration and quality of the DNA were checked using the Nanodrop ND-20oo (Nanodrop, Wilmington, DE, USA) and $1 \%$ agarose gel electrophoresis.

Faecal DNA could be highly degraded (Deagle et al., 2006; Vynne et al., 2012) and therefore, to enhance the success of the analyses, multilocus genotypes were obtained by amplification of a marker no longer than 300 bp (Frantzen et al., 1998). We relied on a panel of 11 autosomal microsatellite DNA loci, ranging from $170 \mathrm{bp}$ to $262 \mathrm{bp}$ : Lut 435 , Lut 453, Lut 457, Lut 615, Lut 715, Lut 717, Lut 733, 
Lut 782, Lut 818, Lut 832, Lut 833 (Dallas \& Piertney, 1998; Dallas et al., 2002).

Amplifications were carried out in $25 \mu \mathrm{L}$ containing 50 ng of genomic DNA, $10 \mu \mathrm{M}$ of each primer, 1OX PCR buffer, o.2 U FIREPol DNA Polymerase (Solis Biodyne, Estonia), $0.25 \mathrm{mM}$ of each dNTP. Each sample was amplified in triplicate for each locus, and negative controls (no added DNA) were included to check the performance of the reactions. In particular, each sample was first amplified three times for loci Lut 435 and Lut 833, selected because of their repeatable results in our previous experiments. Only the samples that produced three PCR products at these loci and only samples whose replicas resulted in the same typing were retained for subsequent analyses (modified by Koelewijn et al., 2010). The selected samples were then amplified three times for the remaining loci, and only samples which provided $50 \%$ or more of positive screening at a locus were considered 'positive' (Lerone et al., 2014). Furthermore, we defined a sample as successfully genotyped if at least six microsatellite loci revealed complete genotype. The reliability of genotypes was estimated using the software Reliotype (Miller et al., 2002) and they were retained if the reliability score was $\geq 90 \%$.

The amplifications were performed as follows: $94^{\circ} \mathrm{C}$ for 2 min and $15 \mathrm{sec}, 45$ cycles at

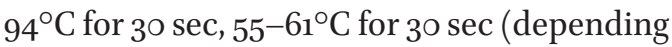
on the microsatellite locus), $72^{\circ} \mathrm{C}$ for 3 o sec, and a final extension at $72^{\circ} \mathrm{C}$ for $5 \mathrm{~min}$. We used a forward primer labelled at the 5 '-end with a fluorescent dye group (FAM and HEX; Sigma-Aldrich, St. Louis, MO, USA), and an internal size standard LIZ5oo (Applied Biosystems, Norwalk, CT, USA). Multilocus genotypes were determined using an $\mathrm{ABI} 3100$ automated sequencing instrument (Applied Biosystems, Norwalk, CT, USA) and then analysed with Geneious software v. R9.1 (Kearse et al., 2012) with microsatellite plug-in, used to check for any stutter peaks or incorrectly called peaks, removing them.

In order to test the robustness of microsatellite assignment, we constructed a consensus genotypes using Gimlet vı.3.3 (Valière, 2002) and estimated the rates of false alleles (FA) and allele drop out (ADO) (Taberlet et al., 1996; Frantz et al., 2003; Hájková et al., 2007; Ferrando et al., 2008; Lerone et al., 2014) with a maximum likelihood-based method implemented in Pedant (Johnson \& Haydon, 2007a, b). GenALEx v. 6.51b2 (Peakall \& Smouse, 2012) was used to identify identical genotypes, the probability of identity (PID) and siblings (PID-sib).

The genetic structure of the population was identified using a Bayesian clustering method implemented in STRUCTURE v. 2.3.4 (Pritchard et al., 2000), run with a burn-in period of 10,000 steps and 1,000,000 repetitions of Markov Chain Monte Carlo (MCMC) to obtain convergence of the parameter values. To establish consistency, $K$, ranging from 2 to 6 , was tested in three independent runs using the admixture model of ancestry and independent allele frequency model (Falush et al., 2003). The selection of the most appropriate number of clusters that best fits the dataset was performed according to posterior probability of data LnP (D) (Garnier et al., 2004) combined the admixture parameter $\alpha$ (Pritchard et al., 2000), and according to Evanno et al. (2005) method, both manually and with the software Structure Harvester (Earl, 2012). The assignment of each individual to clusters was based on genetic data and without any prior geographical information. Each genotype was unambiguously assigned to a cluster when the coefficients of individuals membership $(Q)$ were greater than $70 \%$, while when $Q$ value ranged between $25 \%<Q<70 \%$, the admixed genotypes were assigned to more than one cluster. Finally, the geographic visualization of microsatellite 
cluster assignments was made plotting each genotype on a map.

Starting from clusters identified by STRUCTURE and considering the geographical locations of the samples according to the river basins, we used GENETIX v.4.o5 (Belkhir et al., 2004) to: (I) identify variance among individuals, within and between genotypic groups, visualized in a principal component analysis (PCA) assigning individuals/genotypes both according to the clusters inferred by STRUCTURE and according to the river basin; (II) detect the number of alleles $\left(\mathrm{N}_{\text {tot }}\right)$ and average number of allele per locus $(\mathrm{mN})$. The structure of sub-populations was investigated using $F$-statistics (Wright, 1969) through the inbreeding coefficient $\left(F_{\text {IS }}\right)$, Nei's genetic distance (Nei, 1972), and population differentiation pairwise values $\left(F_{\mathrm{ST}}\right)$ (Weir \& Cockerham, 1984). The latter, together with corresponding $P$ value, was performed in FSTAT v.c2.9.4 (Goudet, 1995). The expected $\left(\mathrm{H}_{\mathrm{e}}\right)$ and observed $\left(\mathrm{H}_{\mathrm{o}}\right)$ heterozygosity and the allelic richness (AR) for all 11 loci over all river basin sub-populations were estimated using the Hierfstat package (Goudet, 2005) in R v. 3.6.1.

The probability of deviation from HardyWeinberg equilibrium as well as Linkage Disequibrium per population (LD) were estimated using GENEPOP v. 4.7 (Raymond \& Rousset, 1995; Rousset, 2008), with subsequent Bonferroni correction applied using the software R.

\section{Bottleneck analysis}

We used the Bottleneck module of the online software CONGRESS (Hoban et al., 2013) to assess the power of the 11 microsatellite loci panel in detecting a bottleneck in the otter population in Italy. We set a medium $(5,000)$ pre-bottleneck population size, a bottleneck population size of 100 (Fumagalli \& Prigioni, 1993) and post-bottleneck population size inferred by a population viability analysis
(PVA) model (Lacy \& Pollak, 2015) using Vortex software (Lacy \& Pollak, 2015; Lacy et al., 2015). In CONGRESS we set the occurrence of the bottleneck to 50 years ago (1970s) and the end of the bottleneck to 15 years ago.

Vortex uses a Monte Carlo simulation of the effects of defined deterministic forces, and demographic, environmental and genetic stochastic events on the viability of living individuals. In brief, the program begins with creating individuals to form the starting population and then generates life cycle events on an annual basis (see also Lacy et al., 2015). Our simulation was performed with two scenarios relative to the differences in sexual maturity that may attained after 2 or 3 years (Mason \& Macdonald, 2009). The assumptions of time were 20 years long. For both scenarios, the simulation of the population was iterated 100 times to generate the distribution of fates that the population might experience. We provided Vortex with some events and biological parameters that were necessary for the PVA model. In particular, we assumed the frequency of ovulation and the frequency of pregnancy per mature female per year of 2.0 and 1.1, respectively, and the fertility of $1-5$ cubs (more often 1-3) (Heggberget \& Christensen, 1994).

Then, to verify a the presence of a recent genetic bottleneck signature, we used BOTTLENECK software v.1.2.02 (Cornuet \& Luikart, 1996; http://www.montpellier.inra.fr/ URLB/bottleneck/bottleneck.html), assuming both infinite allele model (IAM), stepwise mutation model (SMM) and two phase model (TPM, setting $50 \%$ of SMM and with $90 \%$ of SMM). The Sign test and the Wilcoxon test (Luikart et al., 1997; Luikart \& Cornuet, 1998) were used to evaluate the significance. Finally, mode-shift indicator was plotted.

\section{Landscape genetics}

To test for Isolation by Distance (IBD), we performed a pairwise Mantel test using GenALEx 
v.6.51b2 (Peakall \& Smouse, 2012), calculating the Linear Genetic Distance matrix between the samples and the Geographic (Euclidean) Distance, setting the number or permutations of 9,999. Subsequently, we performed an additional Mantel test to correlate the genetic distance and ecological distance (according to ecological corridors). Firstly, we generated a maximum entropy distribution model using MaxEnt v.3.4.1 (Phillips et al., 2006), the values of which were then inverted and used as measures of resistance (Fulgione et al., 2009; Milanesi et al., 2017).

To limit spatial bias, we performed spatial thinning of occurrence records, using the spThin $\mathrm{R}$ package (Aiello-Lammens et al., 2015), with a range of $1 \mathrm{~km}$ and setting the number of replications to 10o. The thinning resulted in 75 occurrence points used for the habitat suitability model. For the model construction, the following 6 spatially explicit variables (SEV) were selected: altitude, slope, water bodies (Categories 4 and 5 of Corine Land Cover, along with rivers), natural vegetation (Category 3 of Corine Land Cover), agricultural vegetation (Category 2 of Corine Land Cover), and anthropogenic elements (Category 1 of Corine Land Cover along with roads and railways). Altitude data and slope were obtained as quantitative variables, with slope calculated using the GDAL function Slope in QGIS 3.4.1. All environmental data was obtained from the National Geographic Portal (http://www.pcn.minambiente.it). The remaining 4 variables were obtained as shapefiles and rendered as continuous rasters by considering the Euclidean distance from each feature, using the GDAL function Proximity (raster distance), and selecting geographical units. Spatial elaboration of the SEV map was done in QGIS v.3.4.1. All SEV s were rendered as raster maps with a resolution of $500 \times 500$ m. In order to avoid collinearity between the predictor variables, Pearson's correlation coefficient was calculated, to ensure none of the variables showed a coefficient higher than o.70 (Dormann et al., 2013). Models were generated using default settings, with a test percentage of $30 \%$ of the presence points, and a number of background points of 30,000 . A regularization parameter of 1.0 was used, the maximum number of iterations was set at 50o, and a jackknife procedure was used to assess variable importance. Performance was estimated for each model by calculating the average test AUC (the area under the receiver operating characteristic curve; Swets, 1988) through five-fold cross-validation. Following this, the model was fit a final time using the complete set of genotyped samples (which were then used as focal nodes in Circuitscape, see below) to obtain resistance values, by considering the inverted values of the Habitat Suitabilty Index (1 - HBI) provided by Maxent. To highlight potential dispersal corridors or barriers, we used an Isolation by Resistance approach (IBR) (McRae \& Beier, 2007) with Circuitscape software (Shah \& McRae, 2008; Anantharaman et al., 2019), based on circuit theory and the use of a resistance surface to generate a cumulative flow map in order to model connectivity across the landscape. We selected the Pairwise mode, calculating the average resistance, using the 8 nearest neighbors. The ecological distance matrix was generated using the gdistance $\mathrm{R}$ package (van Etten, 2017) and was then used to perform a pairwise Mantel test in GenALEX v.6.51b2 (Peakall \& Smouse, 2012), against the genetic distance matrix, setting the number of permutations to 9,999. We interpreted the current map produced by Circuitscape by also looking at the contribution of the eco-geographical variables to the suitable habitat for otters, thus interpreting as corridors or barriers areas with high or low current density and characterized by negatively or positively correlated eco-geographical variables. 


\section{Results}

We defined 6 river basins: the Agri, Basento, Lao, Sinni, Cilento (so named the waterways surveyed in Campania with the Tanagro as the main river), and Abatemarco basins (figs 1 and 2). All collected samples were assigned to a river basin, except two (out of basin) collected on the Galeso and on the Bradano rivers (table 1).

\section{Microsatellite analysis}

DNA was extracted successfully from 189 samples, of which 137 were successfully genotyped (see supplementary fig. Si to check distribution of successful PCR). All our genotypes showed a reliability score $>99 \%$, except for $3 / 136$ that had $90 \%, 93 \%$, and $97 \%$ as reliability score.
Pedant analysis showed no significant ADO and FA at any of the loci were detected, with values ranging from 0.000000 to 0.000002 and from 0.000000 to 0.000004 , respectively. The construction of a consensus genotype allowed to fix 136 unique genetic profiles. The estimated PID of the selected 11 microsatellite panel was o.0o8 using up to three loci, and the PID-sib was o.o11 with seven loci (supplementary fig. S2), showing that these microsatellites allow the identification of unique genotypes even if related individuals are sampled, with a probability of $99 \%$. The 11 considered loci were all polymorphic, with a number of alleles ranging from 2 to 10 , and allelic richness was moderately high, ranging between 1.00 and 4.48 (supplementary table $\mathrm{S}$ ). Estimates of

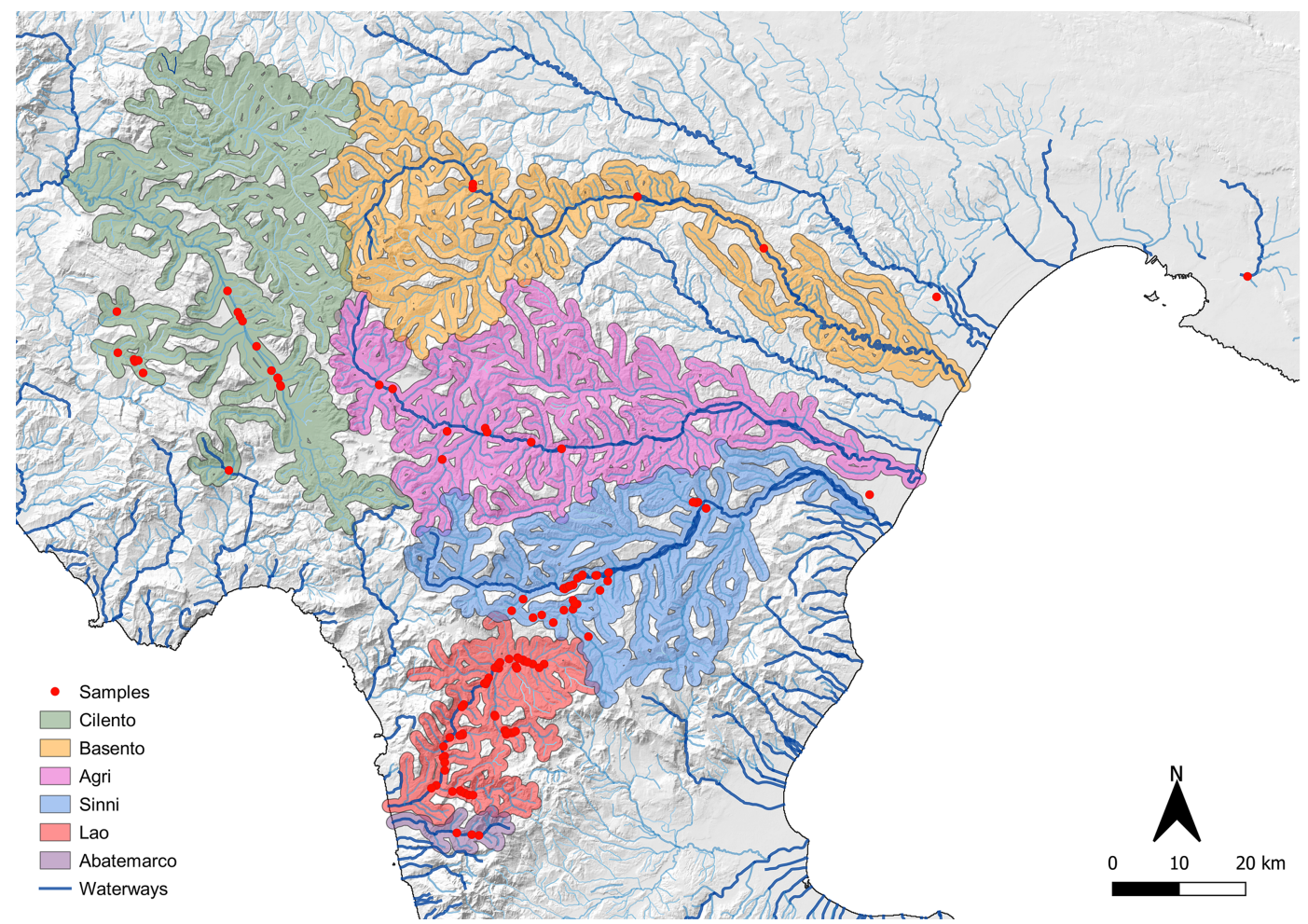

FIGURE 2 Definition of the six main river basins by drawing a buffer area of $1 \mathrm{~km}$ around all waterways connected to the main rivers: in green, the Cilento basin; in pink, the Agri basin; in blue, the Sinni basin; in red, the Lao basin; in orange, the Basento basin; in violet, the Abatemarco basin. Red spots indicate the location of the collected samples. The bold blue lines highlight the main rivers, while the tiny blue lines show all other waterways. 
TABLE 2 Estimate of genetic indices for genotypes of both the meta-population and the sub-populations inferred according to their geographical positions on the six river basins. Population size (n); observed heterozygosity $\left(\mathrm{H}_{\mathrm{o}}\right)$; expected heterozygosity $\left(\mathrm{H}_{\mathrm{e}}\right)$; total number of alleles in the population $\left(\mathrm{N}_{\text {tot }}\right)$; average number of alleles per locus $(\mathrm{mN})$; inbreeding coefficient $\left(F_{\text {IS }}\right) ; P\left(F_{\text {IS }}\right)$ probability value of the inbreeding coefficient; LD, number of loci involved in significant linkage disequilibrium; N.S., not significant, $P$ (HWE), probability of deviation from Hardy Weinberg equilibrium through heterozygote deficit for the meta-population and each population

\begin{tabular}{lrllllllll}
\hline Populations & $\mathrm{n}$ & $\mathrm{H}_{\mathrm{o}}$ & $\mathrm{H}_{\mathrm{e}}$ & $\mathrm{N}_{\text {tot }}$ & $\mathrm{mN}$ & $F_{\text {IS }}$ & $P\left(F_{\text {IS }}\right)$ & ld & $P($ hwe $)$ \\
\hline Meta-population & 136 & 0.4480 & 0.4569 & 50 & 4.5455 & 0.02444 & 0.860 & N.S. & 0.108 \\
Cilento basin & 20 & 0.6470 & 0.4475 & 32 & 2.9091 & -0.41281 & 0.000 & N.S. & 1.000 \\
Agri basin & 17 & 0.4227 & 0.4513 & 34 & 3.0909 & 0.11194 & 0.093 & N.S. & 0.098 \\
Sinni basin & 36 & 0.3911 & 0.3889 & 35 & 3.1818 & 0.01291 & 0.610 & one & 0.079 \\
Lao basin & 54 & 0.4253 & 0.4014 & 37 & 3.3636 & -0.04535 & 0.040 & N.S. & 0.044 \\
Basento basin & 4 & 0.4318 & 0.3125 & 20 & 1.8182 & -0.25275 & 0.049 & N.S. & 1.000 \\
Abatemarco basin & 3 & 0.3333 & 0.2727 & 18 & 1.6364 & 0.15385 & 0.800 & N.S. & 1.000 \\
& & & & & & & & & \\
\hline
\end{tabular}

genetic diversity show that $\mathrm{H}_{\mathrm{o}}$ is always higher than $\mathrm{H}_{\mathrm{e}}$, except for the meta-population and sub-population of the Agri basin (table 2). $\mathrm{H}_{\mathrm{o}}$ values range from 0.647 (for sub-population from the Cilento basin) to 0.333 (for the Abatemarco sub-population). $\mathrm{H}_{\mathrm{e}}$ values range from 0.451 (for the sub-population from the Agri basin) to 0.272 (for the Abatemarco sub-population) (table 2).

The meta-population and all sub-populations were in HWE except for the sub-population on Lao basin (table 2). Test for HWE departure for each locus shows 8/11 loci were in equilibrium (supplementary table $\mathrm{S}_{1}$ ). The $F_{\text {IS }}$ value is statistically significant only for sub-populations from Cilento, Lao and Basento basins (table 2). These sub-populations showed $F_{\text {IS }}<0$ that denotes outbreed of individuals.

\section{Population genetic structure}

According to posterior probability of data and Evanno method, $K=5$ is the most likely value describing population clusterization (supplementary figs $\mathrm{S}_{3}$ and $\mathrm{S}_{4}$, supplementary tables $S_{2}$ and $S_{3}$ ). A total of $5^{\text {o of the } 136}$ genotypes were unambiguously allocated in the 5 putative clusters $K$ (fig. $3 \mathrm{~A}$ ). In particular, samples from the Agri basin were divided in 15 genotypes assigned to cluster 2, segregated in the upper part (young river), and 2 genotypes, located in lower trait (mature river) assigned to cluster 3. The latter also includes 4 genotypes from the Basento basin, 7 samples located in the lower portion of the Sinni river and the 2 genotypes that are outside of any considered basins, but always in the lower part of the rivers they were sampled at. All samples from the Cilento basin $(\mathrm{N}=20)$ were assigned to cluster 5 , and the remaining 86 genotypes ( 54 from Lao basin, 29 samples from Sinni basin and 3 samples from Abatemaco basin) represented multiple sub-populations with admixed genotype (fig. 3B).

The PCA plot of multilocus genotypes accounts for $87.69 \%$ of the total variance. To interpret the distribution of genotypes, we marked the samples in two ways, according to both their geographical location in the river basins (fig. 4A; cfr. fig. 2) and the clustering inferred by the Bayesian analysis (fig. $4 \mathrm{~B}$; cfr. fig. $3 \mathrm{~A}$ ).

The PCA discriminated 3 clearly distinct clusters that showed a tendency to arrange 


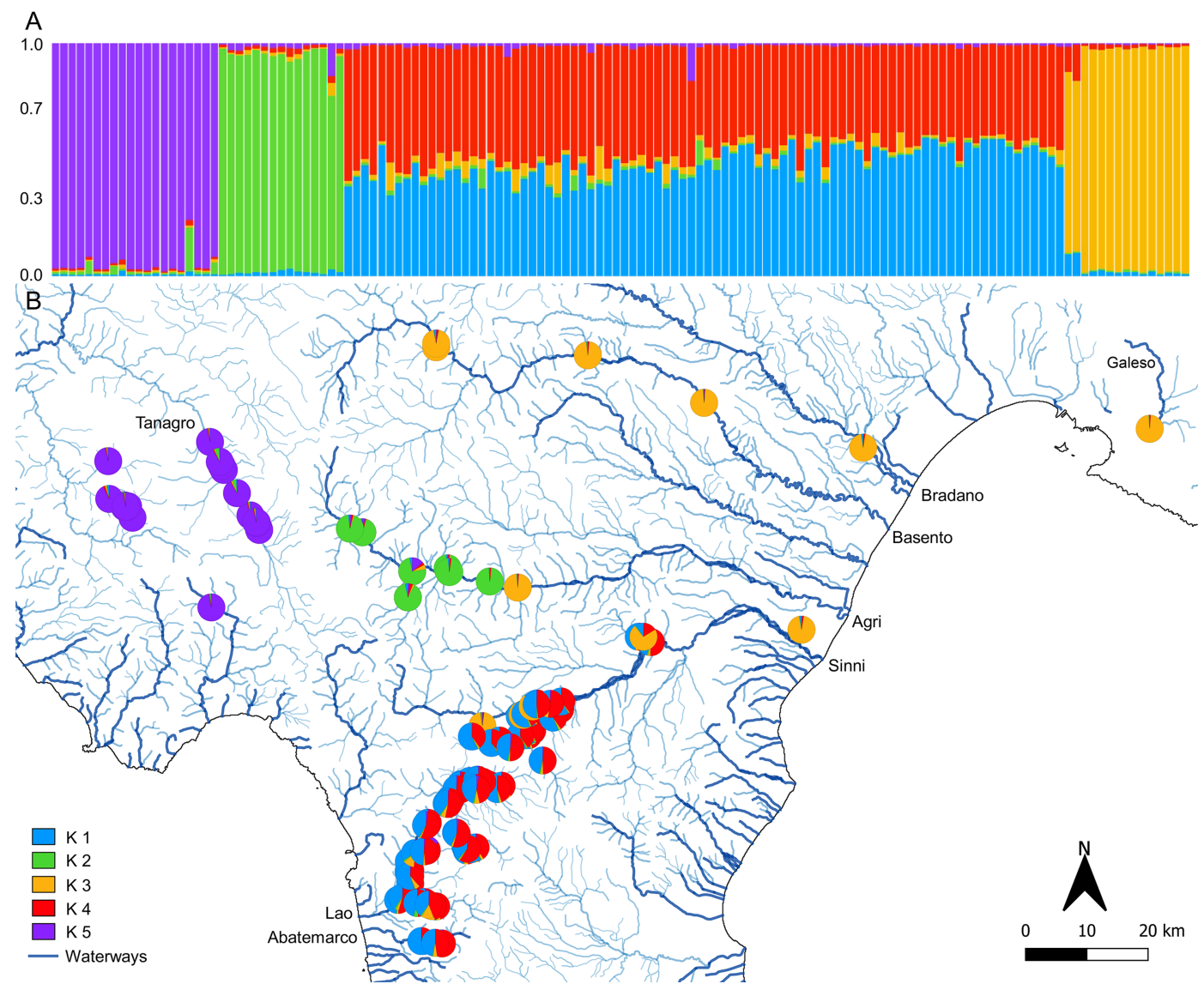

FIGURE 3 Genetic structure and distribution of the Italian otter genotypes in the study area. A) Estimated population structure based on the analysis of 11 microsatellite loci according to STRUCTURE $(K=5)$. Each bar represents a sample analysed. B) Geographic visualisation of genotypes in the study area performed using QGIS 3.4.1 software with base layers acquired from http://www.pnc.miniambiente. it/. Each circle represents a sample analysed. The colours indicate the percentage of assignment of an individual to each cluster: in blue, $K_{1}$; in green, $K_{2}$; in orange, $K_{3}$; in red, $K_{4}$; in violet, $K_{5}$. The bold blue lines highlight the main rivers, while the tiny blue lines show all other waterways.

according to their geographical origins. The genotypes from the Cilento and from the Agri basins are contiguous in the plot (in accordance with the closeness of their corresponding river basins) (fig. $4 \mathrm{~A}$ ), although they show a lower overlap (fig. 4B). Conversely, genotypes from the Sinni, Lao and Abatemarco basins, cluster together in the upper right corner of the plot (fig. 4A), showing a markedly mixed sub-population, in agreement with the cluster assignment by STRUCTURE (figs $3 \mathrm{~A}$ and ${ }_{4} \mathrm{~B}$ ). Interestingly, the genotypes located towards the lower right corner of the plot group together the samples collected at the far ends of the rivers that flow into the Ionian Sea (fig. 4).

The lowest values of $F_{\mathrm{ST}}$ were observed between the system that includes the sub-populations from Sinni, Lao and Abatemarco, even if few samples from Abatemarco did not show significant value. Interestingly, the lowest value of $F_{\mathrm{ST}}$ was between Sinni $v$ s Basento (table 3 ).

The highest values of $F_{\mathrm{ST}}$ were obtained considering genotypes from the Cilento basin 
A

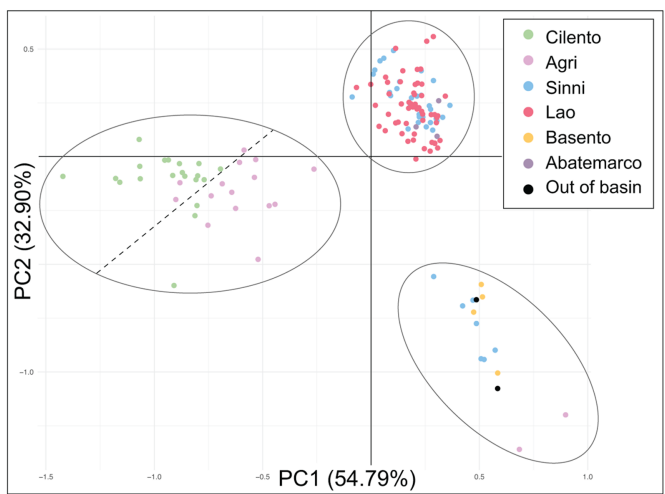

B

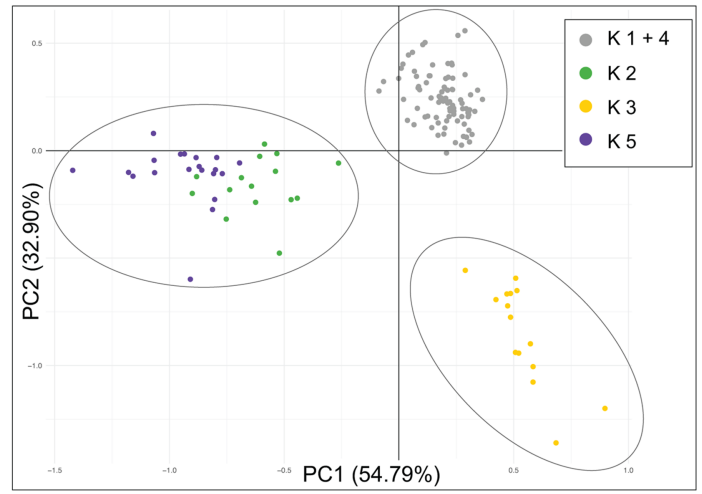

FIGURE 4 Principal Component Analysis (PCA) performed on microsatellite genotypes (dots). Circles show the well-defined spatial groups. A) PCA according to the belonging of genotypes to the six river basins: the Cilento basin (green dots); the Agri basin (pink dots); the Sinni basin (blue dots); the Lao basin (red dots); the Basento basin (orange dots); the Abatemarco basin (violet dots); black dots indicate the samples outside of the main river basins. Dashed line indicates geographically contiguous but genetically different genotypes. B) PCA according to clusters inferred by STRUCTURE: genotypes assigned unambiguously to $K_{2}$ (green dots), to $K_{3}$ (yellow dots), to $K_{5}$ (violet dots). Grey dots represent samples with mixed genotypes assignable to $K_{1}$ and $K_{4}$.

TABLE 3 Matrix of pairwise $F_{\mathrm{ST}}$ (Weir \& Cockerham, 1984) above the diagonal line, and Nei's index (Nei, 1972) values below the diagonal line, between river population systems based on the neutral microsatellite dataset. The $P$ values of $F_{\mathrm{ST}}$ are shown in parentheses. NA not assignable

\begin{tabular}{lcllllc}
\hline Basin & Cilento & Agri & Sinni & Lao & Basento & Abatemarco \\
\hline Cilento & - & $0.165(0.086)$ & $0.211(0.003)$ & $0.207(0.053)$ & $0.303(0.040)$ & $0.221 \mathrm{NA}$ \\
Agri & 0.216 & - & $0.169(0.133)$ & $0.156(0.096)$ & $0.209(0.356)$ & $0.156 \mathrm{NA}$ \\
Sinni & 0.233 & 0.182 & - & $0.004(0.043)$ & $0.099(0.046)$ & $-0.036 \mathrm{NA}$ \\
Lao & 0.231 & 0.167 & 0.013 & - & $0.114(0.036)$ & $-0.026 \mathrm{NA}$ \\
Basento & 0.404 & 0.282 & 0.113 & 0.127 & - & $0.112 \mathrm{NA}$ \\
Abatemarco & 0.285 & 0.262 & 0.055 & 0.054 & 0.164 & -
\end{tabular}

in relation to all the other populations (table 3 ), that show a low level of gene flow only with the sub-population on the Agri river. As expected, these results are also confirmed by the values of genetic distance according to Nei (1972) (table 3).

\section{Population decline or expansion}

The bottleneck module analysis implemented in CONGRESS reported a power value of $55 \%$, proving that the 11 microsatellite panel should be enough to detect a potential bottleneck on 136 genotypes with a post-bottleneck population estimated at about 9oo individuals (see simulation in supplementary fig. $\mathrm{S}_{5}$ and $\mathrm{S} 6$ ).

In the analysis of a bottleneck signature, no significant heterozygosity excess was observed in the Southern-Italian meta-population, under the assumption of both the 


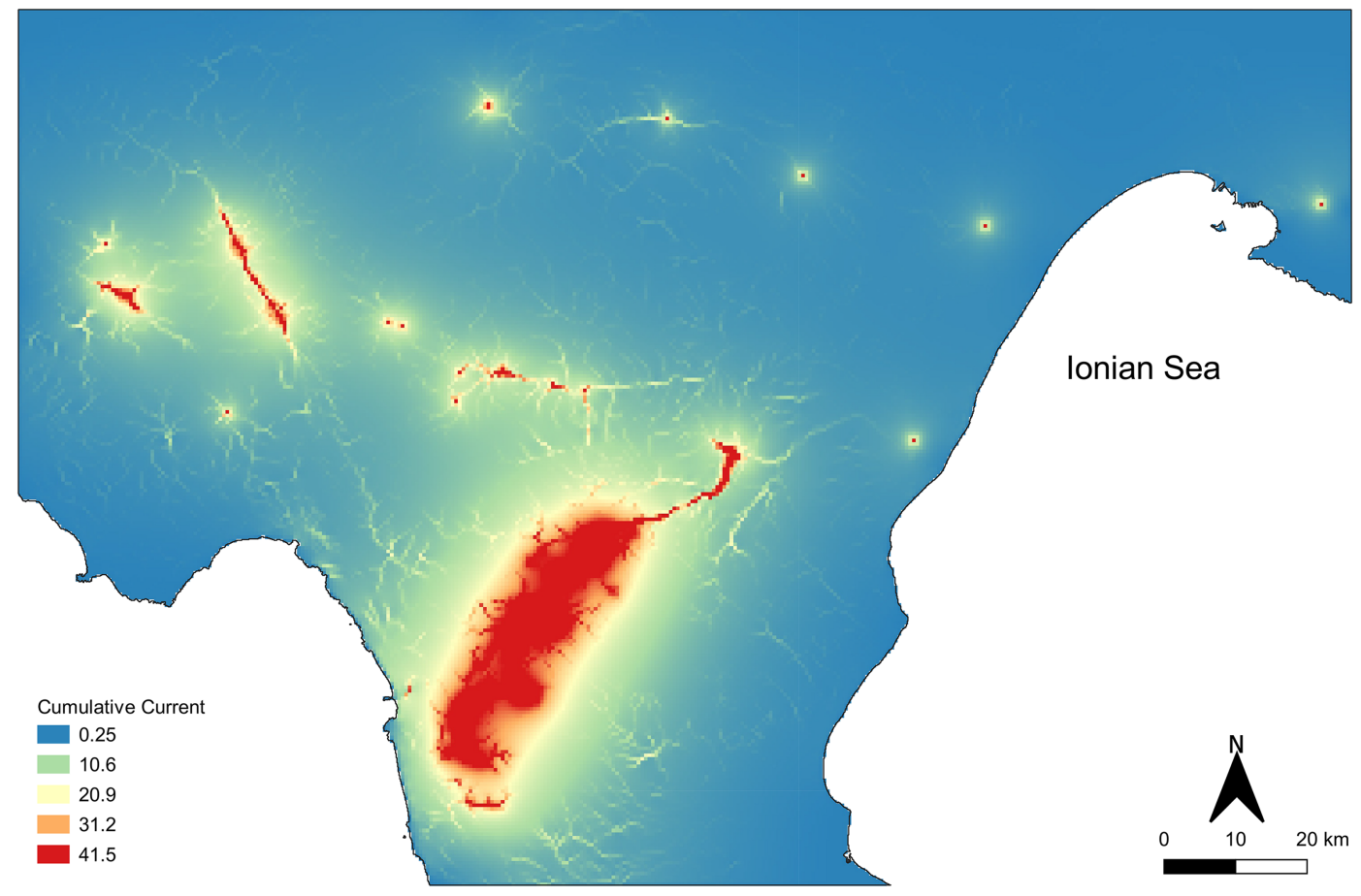

FIGURE 5 Cumulative current map, based on all possible pairs of sampling locations, representing the amount of current flowing through each pixel. Higher current flow represents higher connectivity, and vice versa.

SMM, the IAM and the TPM models as well as confirmed by a normal L-shaped distribution (supplementary fig. $\mathrm{S}_{7}$ )

\section{Landscape genetics}

The Mantel test performed using geographic $\mathrm{x}$ genetic distance was statistically significant (Rxy $=0.264, P=0.0001)$, confirming the presence of IBD.

A map of permeability/resistance to otter dispersion was generated starting from a Habitat Suitability map (average training AUC for the Maxent model equal to o.906 $\mp 0.033$, AUC of final model equal to 0.948 ) which showed distance from water features as the strongest predictor variable, explaining $70 \%$ of the variation.

The current map generated in Circuitscape (fig. 5) represents the connectivity of the landscape, and it shows several well-connected regions, notably a large area of high connectivity between the Abatemarco, Lao, and Sinni river basins and areas of medium connectivity between the Cilento river basin (mostly the Tanagro river) and the Agri river, as well as between the Agri and Sinni rivers. The Basento river appears to be the most isolated of the main rivers considered in this study, both along the river course and from the other basins. The resistance surface generated mostly followed the waterways in the study area, which scored the lowest resistance. As for geographic $x$ genetic distance (fig. 6A), the Mantel test performed using ecological distance $\mathrm{x}$ genetic distance (fig. 6B), was statistically significant $(\mathrm{Rxy}=0.217, P=0.0001)$.

\section{Discussion}

The otters analysed in this study have a relevant importance because they represent the "core" population in the Italian distribution 

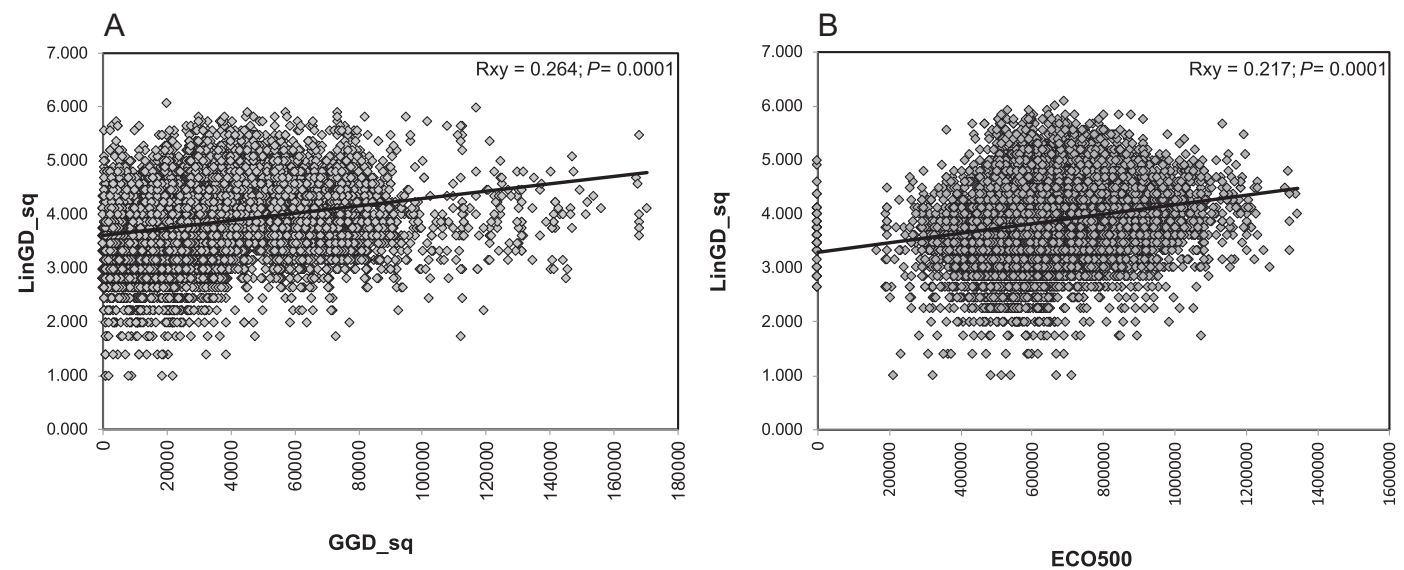

FIGURE 6 Mantel test for A) the correlation between geographic distance (GGDsq) and genetic distance $(\operatorname{LinGD})(\mathrm{Rxy}=0.264, \mathrm{P}=0.0001)$ and for $\mathrm{B})$ the correlation between resistance distance (a measure of ecological distance $)\left(\mathrm{ECO}_{5} \mathrm{Oo}\right)$ and $\mathrm{LinGD}(\mathrm{Rxy}=0.217, \mathrm{P}=0.0001)$.

range (Balestrieri et al., 2016; Buglione et al., 2020c), and could be considered an ESU (Mucci et al., 2010). Understanding the genetic structure could be useful to speculate about evolution of the meta-population that could remain stable or could experience an expansion, connecting with all other otters in Europe, currently geographically and genetically isolated (Spagnesi, 2002; Randi et al., 2003; Mucci et al., 2010).

\section{Non-invasive genetics}

The use of indirect and non-invasive characterization of faecal DNA (Randi et al., 2003; Lerone et al., 2014; Buglione et al., 2020c) combined with our extensive surveys over large areas, that include all of the main areas occupied by otters in South Italy (Prigioni et al., 2006a), was revealed to be an advantageous tool to study an elusive and nocturnal species. This was in spite of using a source of information (not always exhaustive) that is hard to analyse (Pompanon et al., 2005; Ferrando et al., 2008; Lerone et al., 2014).

The analysis at the 11 microsatellite loci showed no significant ADO and FA at any of them, probably because of careful interpretation of the electropherograms and the cleaning of dirty data during the calling of the peaks, that allowed to avoid many errors due to stutter bands or false alleles, reducing genotyping errors.

\section{Genetic variability}

The genetic variability in the Italian otter populations analysed is consistent with other studies that, partially of entirely, used our Lut microsatellite panel (Pertoldi et al., 2001; Dallas et al., 2002; Randi et al., 2003; Janssens et al., 2008; Mucchi et al., 2010; Geboes et al., 2016). In particular, the average number of alleles per locus in the Italian meta-population $(\mathrm{mN}=4.5)$ is similar to the one reported for the otter in France by Geboes et al. (2016) $(\mathrm{mN}=4.7)$ and Janssens et al. (2008) $(\mathrm{mN}=4.0-4.8)$, in Portugal $(\mathrm{mN}=4.7)$, in Slovakia $(\mathrm{mN}=4.4)$ and other European countries by Mucci et al. (2010).

Also, the values of heterozygosities were similar to those found in western Wales and south-western England (Dallas et al., 2002), in Denmark (Pertoldi et al., 2001; Randi et al., 2003; Honnen et al., 2011; Mucci et al., 2010) and in England (Mucci et al., 2010), with $\mathrm{H}_{\mathrm{e}}$ of about 0.40. Conversely, the Italian meta-population showed a value of both average number 
of alleles per locus and $\mathrm{H}_{\mathrm{e}}$ lower than otters in Germany and in Sweden (Randi et al., 2003; Honnen et al., 2011; Mucci et al., 2010).

Our meta-population was in mutation-drift equilibrium and only the Lao sub-population was not in HWE which is probably due to uncharacterized genotype errors or, according to Mucci et al. (2010), possibly due to the presence of a Wahlund effect (Wahlund, 1928).

\section{Population genetic structure}

Structure analysis discriminates 5 inferred sub-populations that cluster in at least 4 groups, 3 of which can be identified with geographically defined sub-populations (Cilento, Agri and Basento). The fourth group is an admixture of genotypes from Sinni, Lao and Abatemarco rivers. These also highlight the lowest $F_{\mathrm{ST}}$ value, suggesting a consistent gene flow in the southern portion of our study area.

The genotypes from the Cilento and Agri basins, geographically very close, are allocated in two clusters with distinct genetic identities. This is probably because the Vallo di Diano, a plane that divides the Alta valle dell'Agri (south-western part of Basilicata region) from the river system in Campania, is crossed by a network of artificial canals and many other anthropic structures (i.e., roads, railways) representing an ecological corridor difficult to cross for otters (Philcox et al., 1999; Guter et al., 2005; Grilo et al., 2009; Poledník et al., 2011; Fabrizio et al., 2019; Lapini et al., 2020), as corroborated by reports of otters found dead on road, likely killed in road accidents (Fabrizio et al., 2019).

The genotypes of the Basento, Bradano and Galeso rivers seem to have dispersed at the far end of the Agri and Sinni rivers (all rivers flowing in the Ionian sea). Could this be an evidence of dispersal of these otters along the coastal sea line? It is reported that the Eurasian otter, thanks to its plasticity, may live along the sea coast (Elmhirst, 1938; Kruuk \& Hewson, 1978; Chanin, 1985; Panzacchi et al., 2011) and can expand its home range to include salt water when suitable prey fish are scarce (Crowley et al., 2013; Lanszki et al., 2014; Mulville, 2015; Hong et al., 2019), like other medium-sized carnivores (Doncaster \& Woodroffe, 1993; Eide et al., 2004), even though it requires access to fresh water for the cleaning of the fur (Kruuk \& Balharry, 1990; Beja, 1996). Furthermore, many reports from zoophilic enthusiasts (on social networks) would corroborate this hypothesis, but further investigations are necessary. However, our results seem to be the first evidence based on genetic data suggesting the use of the sea as a way to spread to new fluvial areas, bypassing mountains and/or median river courses and their dendritic networks. This hypothesis, of movement of the otters via the sea, would also explain the unexpected result of the landscape genetics analysis. Indeed, the value of the correlation between genetic and ecological distances (identified according to ecological corridors on mainland) is not significantly higher than the one of the correlation between genetic distance and geographical distance.

\section{Landscape genetics and demographic history}

The landscape approach was useful to interpret the pattern of the population genetic structure (Coulon et al., 20o6; Adams et al., 2016). Assuming that the natural environment is not an isotropic space, it can be interpreted in terms of different permeability to dispersal (potential corridors or barriers) highlighting trajectories, that in this case are in agreement with the genetic structure of the meta-population. Indeed, the reciprocal relationship between populations underlines a high level of admixture among the southernmost populations (on the Lao, Sinni, and Abatemarco rivers) falling within the area of highest permeability to otter dispersal (fig. 5). The northernmost area, which includes the 
Cilento basin (with the Tanagro river) and the uppermost part of the Agri river, highlights some ecological corridors which are probably responsible for the genetic closeness between the otters of these populations. It is interesting to note that the landscape between the Basento and Agri rivers is interested by large patches with low connectivity for otters (probably due to lower density of the tributaries). This landscape state clashes with the admixture of genotypes observed from the river basins flowing to the Ionian Sea, especially those from the lower parts of the river axis, corroborating the hypothesis of a sea dispersal pathway that could connect these populations. This suggests that the otter is capable of dispersing into the landscape according to new and unexpected ecological corridors. Could this ability (to enhance connectivity) have saved it from a probable bottleneck that in the past would have isolated populations from each other (Loy et al., 2009)? In fact, the Italian populations were certainly disconnected from the European population, but probably did not suffer, as a whole, from a significant bottleneck signature (see also Randi et al., 2003). Even if the lack of disclosure of genetic bottleneck might be due either to the high mutation rate of STR s (Maruyama \& Fuerst, 1985; Cornuet \& Lurikart, 1996) or the long time elapsed since the presumed demographic collapse. Probably, the lack of surveys on large areas of the peninsula could have given this deceptive feeling. Further analysis could help clarify this intriguing situation.

Our study points out that otter populations in southern Italy are displaying a favorable conservation status, as suggested by their genetic variability and their potential ability of dispersion.

Analysing the internal gene flow in the core area, the organization into populations, and connectivity between river catchments, we provide useful data to understand the future shaping of the distribution of the Italian otter meta-population, that has only recently experienced a recolonisation of the northern Italian territories. These data could be useful to predict dynamics of expansion affecting the whole meta-population in the near future. All this in order to help the definition of programs for the restoration of this endangered species, for example, by regulating fishing to reduce conflicts and protect the prey availability, controlling the construction of physical barriers (i.e., dam), avoiding pollution and hunting according to the National Action Plan for Otter Conservation (Panzacchi et al., 2011).

\section{Acknowledgments}

We would like to thank Ente Parco Nazionale del Pollino and in particular Dr. Pietro Serroni, Ente Parco Nazionale del Cilento, Vallo di Diano e Alburni, Ente Parco Nazionale dell'Appennino Lucano, Val d'Agri-Lagonegrese and in particolar Dr. Donata Coppola and Dr. Luciano Ferraro, and Istituto Zooprofilattico Sperimentale della Puglia e della Basilicata. We are also grateful to Dr. Valeria Maselli and Dr. Rosita Rinaldi for their advice in some analyses. Finally we thank three anonymous reviewers for the constructive remarks, and especially one of them who went into great detail and helped us improve this paper considerably. The authors declare that they have no competing interests. Conceptualization: M.B., D.F. and S.P.; Methodology: M.B., D.F., S.P. and C.T.; Sample collection: M.B., D.F., S.P., T.N., A.P., L.D., L.P., V.C. and R.B.; Formal analysis: M.B., D.F., S.P., C.T.; Investigation: M.B., D.F., S.P. and C.T.; Supervision: M.B., D.F. and S.P.; Writing - original draft: M.B., D.F. and S.P.; Writing - review \& editing: M.B., D.F., S.P., and C.T. 


\section{Supplementary material}

Supplementary material is available online at: https://doi.org/10.6o84/mg.figshare.12618695

\section{References}

Adams, R.V., Lazerte, S.E., Otter, K.A. \& Burg, T.M. (2016) Influence of landscape features on the microgeographic genetic structure of a resident songbird. Heredity, 117, 63-72.

Aiello-Lammens, M.A., Boria, R.A., Radosavljevic, A., Vilela, B. \& Anderson R.P. (2015) spThin: an R package for spatial thinning of species occurrence records for use in ecological niche models. Ecography, 38, 541-545.

Alves, P.C., Melo-Ferreira, J., Branco, M., Suchentrunk, F., Ferrand, N. \& Harris, D.J. (2008) Evidence for genetic similarity of two allopatric European hares (Lepus corsicanus and L. castroviejoi) inferred from nuclear DNA sequences. Mol. Phylog. Evol., 46, 1191.

Anantharaman, R., Hall, K., Shah, V. \& Edelman, A. (2019) Circuitscape in Julia: High performance connectivity modelling to support conservation decisions. arXiv preprint arXiv:19o6.03542.

Arrendal, J., Walker, C.W., Sundqvist, A.K., Hellborg, L. \& Vilà, C. (2004) Genetic evaluation of an otter translocation program. Conserv. Genet., 5 , 79-88.

Balestrieri, A., Remonti, L. \& Prigioni, C. (2016) Towards extinction and back: decline and recovery of otter populations in Italy. In: Angelici F.M. (Ed.) Problematic Wildlife. A Cross-Disciplinary Approach, pp. 91-105. Springer International Publishing, Cham (Switzerland).

Balestrieri, A., Remonti, L., Smiroldo, G., Prigioni, C. \& Reggiani, G. (2008) Surveying otter Lutra lutra distribution at the southern limit of its Italian range. Hystrix, 19.

Beja, P.R. (1996) An analysis of otter Lutra lutra predation on introduced American crayfish
Procambarus clarkii in Iberian streams. J. Appl. Ecol., 1156-1170.

Belkhir, K., Borsa, P., Chikhi, L., Raufaste, N. \& Bonhomme F. (2004) GENETIX 4.05, logiciel sous Windows TM pour la génétique des populations. Laboratoire Génome, Populations, Interactions, CNRS UMR 5000, Université de Montpellier II, Montpellier (France).

Bertolino, S., Colangelo, P., Mori, E. \& Capizzi, D. (2015) Good for management, not for conservation: an overview of research, conservation and management of Italian small mammals. Hystrix, 26, 25-35.

Buglione, M., Maselli, V., Rippa, D., de Filippo, G., Trapanese, M. \& Fulgione, D. (2018) A pilot study on the application of DNA metabarcoding for non-invasive diet analysis in the Italian hare. Mamm. Biol., 88, 31-42.

Buglione, M., Petrelli, S., de Filippo, G., Troiano, C., Rivieccio, E., Notomista, T., Maselli, V., di Martino, L., Carafa, M., Gregorio, R., Latini, R., Fortebraccio, M., Romeo, G., Biliotti, C. \& Fulgione, D. (2020a) Contribution to the ecology of the Italian hare (Lepus corsicanus). Sci. Rep., 10, 13071. doi: 10.1038/s41598-020-70013-1.

Buglione, M., Petrelli, S., Notomista, T., de Filippo, G., Gregorio, R. \& Fulgione, D. (2020b) Who is who? High Resolution Melting analysis to discern between hare species using noninvasive sampling. Conserv. Genet. Resour. doi: 10.1007/s12686-o2o-01153-9.

Buglione, M., Petrelli, S., Troiano, C., Notomista, T., Rivieccio, E. \& Fulgione, D. (2020c) The diet of the otters (Lutra lutra) on the Agri river system, one of the most important presence site in Italy: a molecular approach. PeerJ, 8, e96o6. doi: 10.7717/peerj.96o6.

Boitani, L., Lovari, S. \& Vigna Taglianti A. (2003) Carnivora - Artiodactyla. In: Boitani L., Lovari S. \& Vigna Taglianti A. (Eds) Fauna d'Italia, Mammalia III, pp. 226-234. Calderini, Bologna.

Cassola, F. (1986) La Lontra in Italia. Censimento, distribuzione e problemi di conservazione 
di una specie minacciata. In: Cassola F. (Ed.) The Otter in Italy. Survey, Distribution and Conservation of an Endangered Species, pp 135. WWF Italia, Serie Atti e Studi n.5, Roma.

Chanin, P. (1985). The Natural History of Otters. Croom Helm, London.

Colangelo, P., Aloise, G., Franchini, P., Annesi, F. \& Amori, G. (2012) Mitochondrial DNA reveals hidden diversity and an ancestral lineage of the bank vole in the Italian peninsula. J. Zool., 287, $41-5^{2}$.

Conroy, J.W. \& Chanin, P.R. (2000) The status of the Eurasian otter (Lutra lutra) in Europe. A review. J. Intern. Otter Survival Fund, 1, 7-28.

Cornuet, J.M. \& Luikart, G. (1996) Description and power analysis of two tests for detecting recent population bottlenecks from allele frequency data. Genetics, 144, 2001-2014.

Coulon, A., Guillot, G., Cosson, J.F., Angibault, J.M.A., Aulagnier, S., Cargnelutti, B., Galan, M. \& Hewison, A.J.M. (2006) Genetic structure is influenced by landscape features: empirical evidence from a roe deer population. Mol. Ecol., 15, 1669-1679.

Crowley, S., Johnson, C.J. \& Hodder, D.P. (2013) Spatio-temporal variation in river otter (Lontra Canadensis) diet and latrine site activity. Ecoscience, 20, 28-39.

Dallas, J.F., Carss, D.N. \& Marshall, F. (2000) Sex identification of the Eurasian otter Lutra lutra by PCR typing of spraints. Conserv. Genet., 1, 181-183

Dallas, J.F., Marshall, F., Piertney, S.B., Bacon, P.J. \& Racey, P.A. (2002) Spatially restricted gene flow and reduced microsatellite polymorphism in the Eurasian otter Lutra lutra in Britain. Conserv. Genet., 3, 15-228.

Dallas, J.F. \& Piertney, S.B. (1998) Microsatellite primers for the Eurasian otter. Mol. Ecol., 7, 1248-1251.

Deagle, B.E., Eveson, J.P. \& Jarman, S.N. (2006) Quantification of damage in DNA recovered from highly degraded samples - a case study on DNA in faeces. Front. Zool., 3, 11.
Doncaster, C.P. \& Woodroffe, R. (1993) Den site can determine shape and size of badger territories: implications for group-living. Oikos, 66, 88-93.

Dormann, C.F., Elith, J., Bacher, S., Buchmann, C., Carl, G., Carré, G., García Marquéz, J.R., Gruber, B., Lafourcade, B., Leitão, P.J., Münkemüller, T., McClean, C., Osborne, P.E., Reineking, B., Schröder, B., Skidmore, A.K., Zurell, D. \& Lautenbach, S. (2013) Collinearity: a review of methods to deal with it and a simulation study evaluating their performance. Ecography, 36, 27-46.

Duplaix, N. \& Savage, M. (2018) The Global Otter Conservation Strategy. IUCN/SSC Otter Specialist Group, Salem, Oregon, USA.

Earl, D.A. (2012) STRUCTURE HARVESTER: a website and program for visualizing STRUCTURE output and implementing the Evanno method. Conserv. Genet. Resour., 4, $359-361$.

Eide, N.E., Jepsen, J.U. \& Prestrud, P. (2004) Spatial organization of reproductive Arctic foxes Alopex lagopus: responses to changes in spatial and temporal availability of prey. J. Anim. Ecol., 73, 1056-1068.

Elmhirst, R. (1938). Food of the otter in the marine littoral zone. Scotl. Nut., 1938, 99-102.

Evanno, G., Regnaut, S. \& Goudet, J. (2005) Detecting the number of clusters of individuals using the software structure: a simulation study. Mol. Ecol., 14, 2611-262o.

Fabrizio, M., Di Febbraro, M. \& Loy, A. (2019) Where will it cross next? Optimal management of road collision risk for otters in Italy.J. Environ. Manag., 251, 1096o9.

Falush, D., Stephens, M. \& Pritchard, J.K. (2003) Inference of population structure using multilocus genotype data: linked loci and correlated allele frequencies. Genetics, 164, 1567-1587.

Ferrando, A., Lecis, R., Domingo-Roura, X. \& Ponsà, M. (2008) Genetic diversity and individual identification of reintroduced otters (Lutra 
lutra) in north-eastern Spain by DNA genotyping of spraints. Conserv. Genet., 9, 129-139.

Frantz, A.C., Pope, L.C., Carpenter, P.J., Roper, T.J., Wilson, G.J., Delahay, R.J. \& Burke T. (2003) Reliable microsatellite genotyping of the Eurasian badger (Meles meles) using faecal DNA. Mol. Ecol., 12, 1649-1661.

Frantzen, M.A.J., Silk, J.B., Ferguson, J.W.H., Wayne, R.K. \& Kohn, MH. (1998) Empirical evaluation of preservation methods for faecal DNA. Mol. Ecol., 7, 1423-1428.

Fulgione, D., Maselli, V., Pavarese, G., Rippa, D. \& Rastogi, R.K. (2009) Landscape fragmentation and habitat suitability in endangered Italian hare (Lepus corsicanus) and European hare (Lepus europaeus) populations. Eur. J. Wildl. Res., 55, 385-396.

Fumagalli, R. \& Prigioni, C. (1993) Evoluzione della distribuzione della lontra (Lutra lutra) in Italia e possibilità di sopravvivenza dei nuclei residui. Suppl. Ric. Biol. Selvaggina, 21, 189-199.

Fusillo, R., Marcelli, M. \& Boitani, L. (2004) Progetto di ricerca sulla ecologia della lontra nel Parco Nazionale del Cilento e Vallo di Diano. Relazione delle attività di ricerca 2003-2004. Università di Roma “La Sapienza”, Parco Nazionale del Cilento e Vallo di Diano. [in italian]

Garnier, S., Alibert, P., Audiot, P., Prieur, B. \& Rasplus, J.Y. (2004) Isolation by distance and sharp discontinuities in gene frequencies: implications for the phylogeography of an alpine insect species, Carabus solieri. Mol. Ecol., 13, 1883-1897.

Geboes, A.L., Rosoux, R., Lemarchand, C., Hansen, E. \& Libois, R. (2016) Genetic diversity and population structure of the Eurasian otter (Lutra lutra) in France. Mamm. Resear., 61, 121-129.

Giovacchini, S., Marrese, M. \& Loy A. (2018) Good News from the South: Filling the Gap between Two Otter Populations in Italy. IUCN Otter Spec. Group Bull., 35, 212-221.

Goossens, B., Chikhi, L., Utami, S.S., de Ruiter, J. \& Bruford, M.W. (2000) A multi-sample, multiextracts approach for microsatellite analysis of faecal samples in an arboreal ape. Conserv. Genet., 1, 157-162.

Goudet, J. (1995) FSTAT: A computer program to calculate F-statistics. J. Hered., 86, 485-486.

Goudet, J. (2005) Hierfstat, a package for $\mathrm{R}$ to compute and test hierarchical F-statistics. Mol. Ecol. Notes, 5, 184-186.

Grilo, C., Bissonette, J.A. \& Santos-Reis, M. (2009) Spatial-temporal patterns in Mediterranean carnivore road casualties: consequences for mitigation. Biol. Conser., 142, 301-313.

Guter, A., Dolev, A., Saltz, D. \& Kronfeld-Schor, N. (2005) Temporal and spatial influences on road mortality in otters: conservation implications. Isr. J. Ecol. Evol., 51, 199-207.

Hajkova, P., Pertoldi, C., Zemanova, B., Roche, K., Hajek, B., Bryja, J. \& Zima, J. (2007) Genetic structure and evidence for recent population decline in Eurasian otter populations in the Czech and Slovak Republics: implications for conservation. J. Zool., 272, 1-9.

Heggberget, T.M. \& Christensen, H. (1994) Reproductive timing in Eurasian otters on the coast of Norway. Ecography, 17, 339-348.

Hoban, S., Gaggiotti, O. \& Bertorelle, G. (2013) Sample Planning Optimization Tool for conservation and population Genetics (SPOTG): a software for choosing the appropriate number of markers and samples. Methods Ecol. Evol., 4, 299-303.

Hong, S., Gim, J.S., Kim, H.G., Cowan, P.E. \& Joo, G.J. (2019) A molecular approach to identifying the relationship between resource use and availability in Eurasian otters (Lutra lutra). Canad.J. Zool., 97, 797-804.

Honnen, A.C., Petersen, B., Kaßler, L., Elmeros, M., Roos, A., Sommer, R.S. \& Zachos, F.E. (2011) Genetic structure of Eurasian otter (Lutra lutra, Carnivora: Mustelidae) populations from the western Baltic sea region and its implications for the recolonization of north-western Germany.J. Zool. Syst. Evol. Res., 49, 169-175.

Jansman, H.A.H., Chanin, P.R.F. \& Dallas, J.F. (2001) Monitoring otter populations by DNA typing of spraints. IUCN Otter Spec. Group Bull., 18, 12-19. 
Janssens, X., Fontaine, M.C., Michaux, J.R., Libois, R., de Kermabon, J., Defourny, P. \& Baret, P.V. (2008) Genetic pattern of the recent recovery of European otters in southern France. Ecography, 31, 176-186.

Johnson, P.C. \& Haydon, D.T. (2007a) Maximumlikelihood estimation of allelic dropout and false allele error rates from microsatellite genotypes in the absence of reference data. Genetics, 175, 827-842.

Johnson, P.C. \& Haydon, D.T. (2007b) Software for quantifying and simulating microsatellite genotyping error. Bioinform. Biol. Insights, 1.

Kearse, M., Moir, R., Wilson, A., Stones-Havas, S., Cheung, M., Sturrock, S., Buxton, S., Cooper, A., Markowitz, S., Duran, C., Thierer, T., Ashton, B., Meintjes, P. \& Drummond A. (2012) Geneious Basic: an integrated and extendable desktop software platform for the organization and analysis of sequence data. Bioinformatics, 28, 1647-1649.

Koelewijn, H.P., Pérez-Haro, M., Jansman, H.A.H., Boerwinkel, M.C., Bovenschen, J., Lammertsma, D.R., Niewold, F.J.J. \& Kuiters, A.T. (2010) The reintroduction of the Eurasian otter (Lutra lutra) into the Netherlands: hidden life revealed by noninvasive genetic monitoring. Conserv. Genet., 11, 6o1-614.

Kruuk, H. \& Balharry, D. (1990) Effects of sea water on thermal insulation of the otter, Lutra lutra.J. Zool., 220, 405-415.

Kruuk, H. \& Hewson, R. (1978) Spacing and foraging of otters (Lutra lutra) in a marine habitat. $J$. Zool., Lond., 185, 205-212.

Lacy, R.C. \& Pollak, J.P. (2015) Vortex: A Stochastic Simulation of the Extinction Process, Version 10.1. Chicago Zoological Society, Brookfield, Illinois, USA.

Lacy, R.C. Miller, P.S. \& Traylor-Holzer, K. (2015) Vortex 10 User's Manual. 15 April 2015 update. IUCN SSC Conservation Breeding Specialist Group and Chicago Zoological Society, Apple Valley, Minnesota, USA.
Lampa, S., Gruber, B., Henle, K. \& Hoehn, M. (2008) An optimisation approach to increase DNA amplification success of otter faeces. Conserv. Genet., 9, 201.

Lanszki, J., Bauer-Haaz, E.A., Szeles, G.L. \& Heltai, M. (2014) Diet and feeding habits of the Eurasian otter (Lutra lutra): experiences from post mortem analysis. Mamm. Study, 40, 1-11.

Lapini, L., Pontarini, R., Molinari, P., Cantarutti, G., Dorigo, L., Pecorella, S., Cesco, N., Commessatti, G., Comuzzo, C., Da Pieve, J., De Belli, E., Dreon, A.L., Giacomuzzi, D., Luca, M., Mareschi, A., Picco, G., Rossi A. \& De Belli, E. (2020) The return of the Eurasian otter in north-eastern Italy. New challenges for biological conservation from Friuli Venezia Giulia Region.J. Mt. Ecol., 20.

Lerone, L., Mengoni, C., Carpaneto, G.M., Randi, E. \& Loy, A. (2014) Procedures to genotype problematic non-invasive otter (Lutra lutra) samples. Acta Theriol., 59, 511-520.

Loy, A., Boitani, L., Bonesi, L., Canu, A., Di Croce, A., Fiorentino, P.L., Genovesi, P., Mattei, L., Panzacchi, M., Prigioni, C., Randi, E. \& Reggiani G. (2010) The Italian action plan for the endangered Eurasian otter Lutra lutra. Hystrix, 21, 19-33.

Loy, A, Bucci, L., Carranza, M.L., De Castro, G., Di Marzio, P. \& Reggiani, G. (2004) Survey and habitat evaluation for a peripheral population of the Eurasian otter in Italy. IUCN Otter Spec. Group Bull., 21A, 1-8.

Loy, A., Carranza, M.L., Cianfrani, C., D’Alessandro, E., Bonesi, L., Di Marzio, P., Minotti, M. \& Reggiani, G. (2009) Otter Lutra lutra population expansion: assessing habitat suitability and connectivity in south-central Italy. Folia Zool., 58, 309-326.

Luikart, G., Allendorf, F.W., Cornuet, J.M. \& Sherwin, W.E. (1997) Distortion of allele frequency distributions provides a test for recent population bottlenecks. J. Hered., 89, 238-247.

Luikart, G. \& Cornuet, J.M. (1998) Empirical evaluation of a test for identifying recently 
bottlenecked populations from allele frequency data. Conser. Biol., 12, 228-237.

MacDonald, S.M. \& Mason, C.F. (1983) The otter Lutra lutra in southern Italy. Biol. Conserv., 25, 95-101.

MacDonald, S.M. \& Mason, C.F. (1994) Status and conservation needs of the otter (Lutra lutra) in the western Palaearctic. Nat. Environ., 67, $1-54$.

Marcelli, M. (2006) Struttura spaziale e determinanti ecologici della distribuzione della lontra (Lutra lutra L.) in Italia. Sviluppo di modelli predittivi per l'inferenza ecologica e la conservazione. D. Phil. Thesis, Università di Roma "La Sapienza". [in italian].

Maruyama, T. \& Fuerst, P.A. (1985) Population bottlenecks and nonequilibrium models in population genetics. II. Number of alleles in a small population that was formed by a recent bottleneck. Genetics, 111, 675-689.

Mason, C. (1995) Habitat quality, water quality and otter distribution. Hystrix, 7, 1-2.

Mason, C.F. \& Macdonald, S.M. (2009). Otters: Ecology and Conservation. Cambridge University Press.

Mason, C.F. \& Wren, C.D. (2001) Carnivora. In: Shore R.F. \& Rattner B.A. (Eds) Ecotoxicology of Wild Mammals, pp. 315-37o. Wiley, Chichester, UK.

McRae, B.H. \& Beier, P. (2007) Circuit theory predicts gene flow in plant and animal populations. Proc. Natl. Acad. Sci., 104, 19885-1989o.

Melo-Ferreira, J., Boursot, P., Carneiro, M., Esteves, P.J., Farelo, L. \& Alves, P.C. (2012) Recurrent introgression of mitochondrial DNA among hares (Lepus spp.) revealed by species-tree inference and coalescent simulations. Syst. Biol., 61, 367 .

Milanesi, P., Holderegger, R., Caniglia, R., Fabbri, E., Galaverni, M. \& Randi, E. (2017) Expert-based versus habitat-suitability models to develop resistance surfaces in landscape genetics. Oecologia, $183,67-79$.
Miller, C.R., Joyce, P. \& Waits LP (2002) Assessing allelic dropout and genotype reliability using maximum likelihood. Genetics, 16o, 357-366.

Mucci, N., Arrendal, J., Ansorge, H., Bailey, M., Bodner, M., Delibes, M., Ferrando, A., Fournier, P., Fournier, C., Godoy, J.A., Hajkova, P., Hauer, S., Heggberget, T.M., Heidecke, D., Kirjavainen, H., Krueger, H.H., Kvaloy, K., Lafontaine, L., Lanszki, J., Lemarchand, C., Liukko, U.M., Loeschcke, V., Ludwig, G., Madsen, A.B., Mercier, L., Ozolins, J., Paunovic, M., Pertoldi, C., Piriz, A., Prigioni, C., Santos-Reis, M., Luis, T.S., Stjernberg, T., Schmid, H., Suchentrunk, F., Teubner, J., Tornberg, R., Zinke, O. \& Randi, E. (2010) Genetic diversity and landscape genetic structure of otter (Lutra lutra) populations in Europe. Conserv. Genet., 11, 583-599.

Mulville, W. (2015) The potential effects of habitat structure on the diet of the Eurasian Otter (Lutra lutra). M.Sc. Thesis, School of Biological, Earth \& Environmental Sciences, University College Cork, Ireland.

Murk, A.J., Leonards, P.E., van Hattum, B., Luit, R., van der Weiden, M.E. \& Smit, M. (1998) Application of biomarkers for exposure and effect of polyhalogenated aromatic hydrocarbons in naturally exposed European otters (Lutra lutra). Environ. Toxicol. Pharmacol., 6, 91-102.

Nei, M. (1972) Genetic distance between populations. Am. Nat., 106, 283-292.

Panzacchi, M., Genovesi, P. \& Loy A. (2011) Piano d'Azione Nazionale per la Conservazione della Lontra (Lutra lutra), Quad. Cons. Natura, 35, Ministero dell' Ambiente - ISPRA, Roma.

Pavanello, M., Lapini, L., Kranz, A. \& Iordan, F. (2015) Rediscovering the Eurasian otter (Lutra lutra) in Friuli Venezia Giulia (NE Italy) and notes on its possible expansion in northern Italy. IUCN Otter Spec. Group Bull., 32, 12-20.

Pertoldi, C., Hansen, M.M., Loeschcke, V., Madsen, A.B., Jacobsen, L. \& Baagoe, H. (2001).Genetic consequences of population decline in the European otter (Lutra lutra): an assessment of 
microsatellite DNA variation in Danish otters from 1883 to 1993. P. Roy. Soc. B-Biol. Sci., 268, $1775^{-1781 .}$

Peakall, R. \& Smouse, P.E. (2012) GenAlEx 6.5: genetic analysis in Excel. Population genetic software for teaching and research-an update. Bioinformatics, 28, 2537-2539.

Philcox, C.K., Grogan, A.L. \& Macdonald, D.W. (1999) Patterns of otter Lutra lutra road mortality in Britain. J. App. Ecol., 36, 748-761.

Phillips, S.J., Anderson, R.P. \& Schapire, R.E. (2006) Maximum entropy modeling of species geographic distributions. Ecol. Model., 4, 231-259.

Poledník, L., Poledníková, K., VětrovcovÁ, J., Hlaváč, V. \& Beran, V. (2011) Causes of deaths of Lutra lutra in the Czech Republic (Carnivora: Mustelidae). Lynx, 42, 145-157.

Pompanon, F., Bonin, A., Bellemain, E. \& Taberlet, P. (2005) Genotyping errors: causes, consequences and solutions. Nat. Rev. Genet., 6, 847-859.

Prigioni, C. (1997) La Lontra. Una vita silenziosa negli ambienti acquatici. Edagricole, Bologna.

Prigioni, C., Balestrieri, A. \& Remonti, L. (2007) Decline and recovery in otter Lutra lutra populations in Italy. Mamm. Rev., 37, 71-79.

Prigioni, C., Balestrieri, A., Remonti, L., Sgrosso, S. \& Priore, G. (2006b) How many otters are there in Italy?, Hystrix It. J. Mamm., 17, 29-36.

Prigioni, C., Remonti, L., Balestrieri, A., Sgrosso, S., Priore, G., Misin, C., Viapiana, M., Spada, S. \& Anania, R. (2005) Distribution and sprainting activity of the otter (Lutra lutra) in the Pollino National Park (Southern Italy). Ethol. Ecol. Evol., 17, 171-18o.

Prigioni, C., Remonti, L., Balestrieri, A., Sgrosso, S., Priore, G., Mucci, N. \& Randi, E. (20o6a) Estimation of European otter (Lutra lutra) population size by fecal DNA typing in Southern Italy. J. Mamm., 8, 855-858.

Pritchard, J.K., Stephens, M. \& Donnelly, P. (2000) Inference of population structure using multilocus genotype data. Genetics, 155, 945-959.
QGIS Development Team (2019) QGIS Geographic Information System. Open Source Geospatial Foundation. URL http://qgis.org.

Randi, E., Davoli, F., Pierpaoli, M., Pertoldi, C., Madsen, A.B. \& Loeschcke, V. (2003) Genetic structure in otter (Lutra lutra) populations in Europe: implications for conservation. Anim Conserv., 6, 93-10o.

Raymond, M. \& Rousset, F. (1995) GENEPOP (version 1.2): population genetics software for exact tests and ecumenism. J. Hered., 86, 248-249.

Reuther, C., Dolch, D., Green, R., Jahrl, J., Roche, K., Ruiz-Olmo, J., Teubner, J. \& Trinidade, A. (2000) Surveying and monitoring distribution and population trends of the Eurasian otter (Lutra Lutra). Habitat, 12, 1-152.

Rousset, F. (2008) Genepop'oo7: A complete reimplementation of the Genepop software for Windows and Linux. Mol. Ecol. Resour., 8, 103-106.

Ruiz-Olmo, J., Lafontaine, L., Prigioni, C., LopezMartin, J.L. \& Santos-Reis M. (2002) Pollution and its effect on otter populations in South-Western Europe. In: Conroy J.W.H., Yoxon P. \& Gutleb A.C. (Eds) Otter Toxicology Conference. Journal of the International Otter Survival Fund, pp. 63-82. International Otter Survival Fund, Broadford.

Saavedra, D. \& Sargatal, J. (1998) Reintroduction of the otter (Lutra lutra) in northeast Spain (Girona Province). Galemys, 10, 191-199.

Santini, A., Lucchini, V., Fabbri, E. \& Randi, E. (2007) Ageing and environmental factors affect PCR success in wolf (Canis lupus) excremental DNA samples. Mol. Ecol. Notes, 7, 955-961.

Scorpio, V., Loy, A., Di Febbraro, M., Rizzo, A. \& Aucelli P. (2016) Hydromorphology meets mammal ecology: river morphological quality, recent channel adjustments and otter resilience. River. Res. Appl., 32, 267-279.

Shah, V.B. \& McRae, B.H. (2008) Circuitscape: a tool for landscape ecology. In: Proceedings of the 7th Python in Science Conference 62-66. Pasadena, California: SciPy. 
Smiroldo, G., Balestrieri, A., Remonti, L. \& Prigioni, C. (2009) Seasonal and habitat-related variation of otter Lutra lutra diet in a Mediterranean river catchment (Italy). Folia Zool., 58, 87.

Spagnesi, M. (2002) Mammiferi d'Italia. In: Spagnesi M. \& De Marinis A.M. (Eds) Quad. Cons. Natura, pp. 236-237, Ministero dell' Ambiente - Istituto Nazionale Fauna Selvatica, Roma, IT.

Swets, J.A. (1988) Measuring the accuracy of diagnostic systems. Science, 240, 1285-1293.

Taberlet, P., Griffin, S., Goossens, B., Questiau, S., Manceau, V., Escaravage, N., Waits, L.P. \& Bouvet, J. (1996) Reliable genotyping of samples with very low DNA quantities using PCR. Nucl. Acid. Res., 24, 3189-3194.

Valiere, N. (2002) GIMLET: a computer program for analysing genetic individual identification data. Mol. Ecol. Notes, 2, 377-379.

van Etten, J. (2017) R Package gdistance: Distances and routes on geographical grids. J. Stat. Softw., 76, 21.

Van Ewijk, K.Y., Knol, A.P. \& De Jong, R.C.C.M. (1997) An otter PVA as a preparation of a reintroduction experiment in the Netherlands. Z. Saugetier, 62, 238-242.
Vega, R., Amori, G., Aloise, G., Cellini, S., Loy, A. \& Searle, J.B. (2010) Genetic and morphological variation in a Mediterranean glacial refugium: evidence from Italian pygmy shrew (Sorex minutus Mammalia, Soricomorpha). Biol. J. Linn. Soc., 100, 774-787.

Vynne, C., Baker, M.R., Breuer, Z.K. \& Wasser, S.K. (2012) Factors influencing degradation of DNA and hormones in maned wolf scat. Anim. Conserv., 15, 184-194.

Wahlund, S. (1928) Zusammensetzung von Populationen und Korrelationserscheinungen vom Standpunkt der Vererbungslehre aus betrachtet. Hereditas, 11, 65-106.

Weir, B.S. \& Cockerham, C.C. (1984) Estimating f-statistics for the analysis of population structure. Evolution, 3, 1358-1370.

Wright, S. (1969) The Theory of Gene Frequencies Evolution and the Genetics of Populations: A Treatise in Three. The University of Chicago Press.

RECEIVED: 3 MAY 2O2O | REVISED AND

ACCEPTED: 25 JUNE 2020

EDITOR: V. NIJMAN 